\title{
Microemulsion Based Gel of Sulconazole Nitrate for Topical Application
}

\section{Topikal Uygulama İçin Mikroemülsiyon Esaslı Sulkonazol Nitrat Jeli}

\author{
(D) Sumedha Prashanth PAYYAL, (D) Narayana Charyulu ROMPICHERLA*, (D) Sandeep Divate SATHYANARAYANA, (D) Ravi Gundadka SHRIRAM, \\ (D) Anoop Narayanan VADAKKEPUSHPAKATH \\ Nitte Gulabi Shetty Memorial Institute of Pharmaceutical Sciences, Nitte (Deemed to be University), Department of Pharmaceutics, Mangaluru, Karnataka, \\ India
}

\begin{abstract}
Objectives: Sulconazole is a broad spectrum antifungal agent of the imidazole class used against dermatophytes and other fungi to treat skin infections. The aim of the present work was to formulate and evaluate a microemulsion-based topical sulconazole gel.

Materials and Methods: Microemulsion formulation of sulconazole nitrate was prepared by using oil, surfactant, cosurfactant and water at different ratios. This was then subjected to clarity and particle size analysis, a centrifugation test, a dilution test, and freeze thawing.

Results: The zeta potential of formulation $\mathrm{F} 1$ was -41.3 and stable. The $\mathrm{pH}$ of the microemulsion formulation was within the range of $\mathrm{pH}$ of skin. $\mathrm{F} 1$ showed a higher percentage amount of drug as compared with the other formulations. The viscosity showed that F1 was optimum. The freezing and thawing results showed there was no phase separation and the formulation was stable. In vitro drug release showed that the drug release from the microemulsion of F1 was higher when compared to the other formulations. It revealed $\mathrm{F} 1$ had the highest drug content of $95.88 \pm 0.3 \%$ and $\%$ cumulative drug release was $88.75 \%$ release in $8 \mathrm{~h}$. The in vivo skin irritation study on rats confirmed that formulation was nontoxic and nonirritant. Conclusion: The present study confirmed the safety of the formulated sulconazole loaded microemulsion gel for topical application.
\end{abstract}

Key words: Microemulsion, sulconazole nitrate, in vitro release, fungal infection

öz

Amaç: Sulkonazol, dermatofitler ve diğer mantarlara karşı deri enfeksiyonlarını tedavi etmek için kullanılan imidazol sınıfının geniş spektrumlu bir antifungal ajanıdır. Mevcut çalışmanın amacı, mikroemülsiyon esaslı topikal sulkonazol jeli formüle etmek ve değerlendirmektir.

Gereç ve Yöntemler: Sulkonazol nitratın mikroemülsiyon formülasyonu, farklı oranlarda yağ, yüzey aktif madde, yardımcı yüzey aktif madde ve su kullanılarak hazırlandı. Formülasyon daha sonra berraklık ve parçacık boyutu analizine, santrifüj testine, seyreltme testine ve donma çözünme testine tabi tutuldu.

Bulgular: Formülasyon F1'in zeta potansiyeli değerinin -41,3 ve kararlı olduğu tespit edildi. Mikroemülsiyon formülasyonunun pH değeri cildin pH aralığı dahilindeydi. F1 formülasyonunun, diğer formülasyonlara kıyasla daha yüksek oranda ilaç yüzdesine sahip olduğu bulundu. Viskozite sonuçları, F1'in optimum olduğunu gösterdi. Donma ve çözünme sonuçları, faz ayrılmasının olmadığını ve formülasyonun stabil olduğunu gösterdi. In vitro ilaç salımı çalışmaları, F1 mikroemülsiyonundan ilaç salımının, diğer formülasyonlara kıyasla daha yüksek olduğunu gösterdi. Bu çalıșma ayrıca, F1'in en yüksek ilaç içeriğine sahip olduğunu (\% 95,88ะ\%0,3) ve \% kümülatif ilaç salımının 8 saat içinde \%88,75 olduğunu ortaya koydu. Sıçanlar üzerinde yapılan in vivo deri irritasyon çalıșması, formülasyonun toksik ve tahriş edici olmadığını doğruladı.

Sonuç: Bu çalışma, formüle edilen sulkonazol yüklü mikroemülsiyon jelin topikal uygulama için güvenirliğini doğrulamıştır.

Anahtar kelimeler: Mikroemülsiyon, sulkonazol nitrat, in vitro salım, mantar enfeksiyonu

*Correspondence: E-mail: narayana@nitte.edu.in, Phone: +919448164750 ORCID-ID: orcid.org/0000-0002-4404-0296

Received: 12.09.2018, Accepted: 17.01.2019

-Turk J Pharm Sci, Published by Galenos Publishing House. 


\section{INTRODUCTION}

Novel drug delivery systems are meant to attain and maintain sufficient therapeutic levels of drug at the target site. In order to overcome the problems connected with traditional modes of drug administration, topical drug delivery was started. For local dermatological disorders topical drug delivery is the effective way for drug administration. Drug delivery through the skin has attracted attention because it avoids the first pass effects, gastrointestinal irritation, and metabolic degradation associated with oral administration. The topical route of administration is also utilized to produce systemic drug effects in some instances. Major attention needs to be paid to new topical formulations to ensure adequate localization of drug within the skin to enhance the local effect or to increase the penetration. Drugs applied topically, mainly for local action, include antifungal, anti-inflammatory, and antiseptic agents as well as skin emollients for protective effects, while this route can also be used for systemic drug delivery!

Microemulsions are thermodynamically stable multicomponent fluids consisting of oil, water, and surfactant. The droplets of microemulsions are in the range of $10-100 \mathrm{~nm}$ in diameter. Since the dispersed particles have diameters less than onefourth of the wavelength of visible light, they do not refract light and that is the reason microemulsions are transparent to the eye. ${ }^{2,3}$

A microemulsion when applied to the skin is expected to penetrate the stratum corneum and to exist intact in the horny layer, resulting in alteration of both the lipid and the polar pathways. The lipophilic domain of the microemulsion interacts with the stratum corneum in a different way. A drug that gets dissolved in the lipid domain of the microemulsion can directly partition into lipid of the stratum corneum. ${ }^{4}$

Sulconazole is a broad spectrum antifungal agent of the imidazole class used against dermatophytes and other fungi to treat skin infections such as ringworm and athlete's foot. It is lipophilic in nature and can be effortlessly formulated for topical delivery by using a microemulsion as topical vehicle for an antifungal effect with several advantages such as ease of preparation, thermodynamic stability, transparent and elegant appearance, increased drug loading, enhanced penetration into the biological membrane, and increased bioavailability compared to conventional dosage form likes cream. Hence, in the present study we developed a sulconazole loaded microemulsion gel for topical delivery and investigated it in terms of physicochemical characterization, drug content, in vitro drug release and kinetic studies, and in vivo skin irritation. ${ }^{5}$

\section{MATERIALS AND METHODS}

\section{Materials}

Sulconazole nitrate was received as a gift sample from Ranbaxy Laboratory, New Delhi, India. Olive oil, Tween 20, and PEG 400 were purchased from HiMedia, Mumbai, India. Propylene glycol and Carbopol 934 were procured from Lobachemie Pvt. Ltd,
Mumbai, India. Triethanolamine was purchased from Rankem Fine Chemicals Ltd., New Delhi, India. All the chemicals and reagents were used of analytical grade.

\section{Methods}

\section{Fourier transform infrared (FTIR) spectroscopy}

FTIR spectroscopy was carried out to check the compatibility between the drug and polymer. Using an IR spectrophotometer (Spectrum one model, Alpha-Bruker, Germany) IR spectra of sulconazole nitrate, Carbopol 934, and physical mixture of sulconazole nitrate and Carbopol were obtained and compared to check the interactions.

\section{Preparation of microemulsion}

Sulconazole nitrate containing $\mathrm{o} / \mathrm{w}$ microemulsion was formulated by water titration method involving the following steps. First, surfactant and cosurfactant were added in fixed ratios to oil followed by sulconazole nitrate. Then bath sonication was performed for $5 \mathrm{~min}$ followed by heating. Later the required quantity of water was added dropwise with constant stirring until the formation of a clear and transparent liquid. A series of microemulsion formulations were prepared using Tween 20 and PEG 400 as the surfactant and cosurfactant and olive oil as the oil. In all these formulations, the amount of sulconazole nitrate was kept constant $(50 \mathrm{mg})$ and the amounts of surfactant, cosurfactant, oil, and cosolvent were varied (Table 1).

\section{Characterization of sulconazole nitrate microemulsion formulations}

\section{Globule size determination}

One drop of the sample was taken on a microscopic glass slide and a cover slip was placed over it and it was observed at $45 x$ resolution under a microscope (Zeiss, Germany). The particle size was measured using BIOVIS software. ${ }^{6}$

\section{Dilution test}

The formulated microemulsions were diluted with distilled water to confirm the type of emulsion and miscibility with the aqueous phase.

\section{Centrifugation test}

This is used to specify the stability of the microemulsion as to whether it is monophasic or not. Samples were centrifuged using a cold centrifuge (CM8plus, Remi Lab World, Mumbai,

\begin{tabular}{llllll}
\multicolumn{5}{l}{ Table 1. Composition of different microemulsion formulations } \\
$\begin{array}{l}\text { Formulation } \\
\text { code }\end{array}$ & $\begin{array}{l}\text { Sulconazole } \\
\text { nitrate }\end{array}$ & $\begin{array}{l}\text { Olive oil } \\
(\% \mathrm{v} / \mathrm{v})\end{array}$ & $\begin{array}{l}\text { S:Cos } \\
\text { ratio }\end{array}$ & $\begin{array}{l}\text { Tween 20/PEG } \\
\text { 400 (\%) }\end{array}$ & $\begin{array}{l}\text { Water } \\
(\%)\end{array}$ \\
\hline F1 & $2 \mathrm{~g}$ & 5.0 & $3: 1$ & 55 & 40.0 \\
\hline F2 & $2 \mathrm{~g}$ & 5.0 & $3: 1$ & 60 & 35.0 \\
\hline F3 & $2 \mathrm{~g}$ & 7.5 & $3: 1$ & 45 & 47.5 \\
\hline F4 & $2 \mathrm{~g}$ & 7.5 & $3: 1$ & 50 & 42.5 \\
\hline F5 & $2 \mathrm{~g}$ & 10 & $3: 1$ & 55 & 35.0 \\
\hline F6 & $2 \mathrm{~g}$ & 10 & $3: 1$ & 60 & 30.0 \\
\hline
\end{tabular}


India) at $10.000 \mathrm{rpm}$ for $30 \mathrm{~min}$ and then were examined for whether the system was monophasic or biphasic.?

\section{Zeta potential determination}

A Malvern Zeta Sizer (Malvern Instruments, UK) was used to measure the zeta potential of the globules on the electrophoresis and electrical conductivity of the microemulsion. Measurements were performed using small volume zeta cells. ${ }^{7}$

\section{Determination of $\mathrm{pH}$}

The $\mathrm{pH}$ of the microemulsion formulations was measured using a digital pH meter (Systronics 335, Ahmedabad, India).

\section{Determination of viscosity}

The viscosity of the formulated microemulsions was determined by Brookfield viscometer DV-II model using spindle number 92 at $20,30,50,60$, and $100 \mathrm{rpm}^{7}$

\section{Freeze thawing}

Freeze thawing was employed to evaluate the stability of the microemulsion formulations. The microemulsion preconcentrates of various formulations were subjected to 3 to 4 freeze thaw cycles, which included freezing at $-10{ }^{\circ} \mathrm{C}$ for $24 \mathrm{~h}$ followed by thawing at $40{ }^{\circ} \mathrm{C}$ for $24 \mathrm{~h}$. The various formulations were then subjected to centrifugation at 3000 rpm for $5 \mathrm{~min}$. The formulations were then visually observed for phase separation. ${ }^{8}$

\section{Preparation of drug loaded microemulsion gel}

The polymers Carbopol 934P and propylene glycol were used to prepare blank gel. Among them Carbopol 934P 1\% gel was optimized for its transparency and its consistency for application on skin. Carbopol 934P (1\%) and propylene glycol (5\%) (as humectants) were added to the required quantity of water with constant stirring and left for hydration for 4-5 $\mathrm{h}$. The microemulsion was in the gel phase and it was left overnight. Finally the required quantity of triethanolamine was added to adjust the $\mathrm{pH} .{ }^{9}$

\section{Evaluation of microemulsion gel}

The prepared drug-containing gel formulations were evaluated for $\mathrm{pH}$ and drug content. For drug content determination, microemulsion gel $(1 \mathrm{~g})$ was weighed and dissolved in a mixture of ethanol:phosphate buffer $\mathrm{pH} 7.4$ (2:3). From this, $2 \mathrm{~mL}$ of the solution was diluted to $50 \mathrm{~mL}$ with the same medium and absorbance was measured at $\lambda_{\max } 227 \mathrm{~nm}$. Blank solution was prepared in the same manner by taking gel without drug. For determination of $\mathrm{pH}, 1 \mathrm{~g}$ of microemulsion gel was dissolved in $100 \mathrm{~mL}$ of distilled water and stored for $2 \mathrm{~h}$ and $\mathrm{pH}$ was measured using a digital pH meter (Systronics 335, Ahmedabad, India). ${ }^{10}$

\section{In vitro drug release and kinetic studies}

The in vitro drug release study of drug from formulations was carried out using an artificial semipermeable membrane (Cellophane) with a Franz diffusion cell. The receptor compartment consisted of $50 \mathrm{~mL}$ of ethanol:phosphate buffer $\mathrm{pH} 7.4$ (2:3), temperature was maintained at $37 \pm 2{ }^{\circ} \mathrm{C}$ and it was stirred using a magnetic stirrer. The microemulsion gel ( $10 \mathrm{mg}$ sulconazole nitrate) was placed on an artificial semipermeable membrane tied to one end of an open ended glass cylinder that was then dipped into the receptor medium on a magnetic stirrer. Samples were taken from the receptor medium over $12 \mathrm{~h}$ at different time intervals and replaced immediately with the buffer. All the samples were analyzed at $227 \mathrm{~nm}$ and the cumulative amount of drug release was calculated. In order to describe the kinetics of the release process of drug in the different formulations, zero order, first order, Higuchi, and Korsmeyer and Peppas models were fitted to the dissolution data of selected formulations using linear regression analysis."

\section{In vivo skin irritation study}

The skin irritation test was carried out on healthy male albino rats (200-250 g) obtained from NUCARE-Nitte (Deemed to be University) with ethical approval from the ethical committee and the document no: is NGSMIPS/IAEC/May-2016/9. The experiments were performed in accordance with the CPCSEA guidelines. The preparation was applied to the properly shaved skin of rats and secured with adhesive tape, and its adverse effects like change in color and skin morphology were checked over 72 h. Two sets of 6 rats were used for the study. Among these 6 were used as the placebo group and the other 6 as the treatment group. The animals were observed for any sign of erythema and edema over different time intervals.12,13

\section{RESULTS}

\section{Fourier transform infrared spectroscopy}

The IR spectra of pure drug sulconazole nitrate (Figure 1), Carbopol 940P (Figure 2), and a physical mixture of sulconazole nitrate with Carbopol 940P (Figure 3) were obtained and interpreted for spectral data comparison for (Figure 1).

Microemulsion formulations of sulconazole nitrate were prepared by water titration. According to the definition, a microemulsion must be clear and transparent in nature. All the formulations were transparent and clear and without any precipitation, which indicated the formation of good microemulsions.

\section{Evaluation of microemulsion of sulconazole nitrate}

\section{Globule size determination}

Microemulsions are thermodynamically stable, transparent systems having particle size $<100 \mathrm{~nm}$. Globule size is a very important evaluation parameter because the therapeutic effectiveness of a microemulsion depends on its globule size. The formulated microemulsions showed globule size between $243.8 \pm 0.02 \mu \mathrm{m}$ and $679.2 \pm 0.01 \mu \mathrm{m}$. Formulation F1, with the highest proportions of surfactant and cosurfactant with a fixed amount of oil, showed the lowest mean particle diameter, whereas formulation F6, with the highest proportion of surfactant and a fixed amount of oil, showed the highest mean particle diameter.

\section{Dilution test}

The dilution test is based on the fact that an emulsion is only miscible with the liquid that forms the continuous phase. 


\section{Centrifugation test}

The data for the formulations for stability for monophasic nature are shown in Table 2.

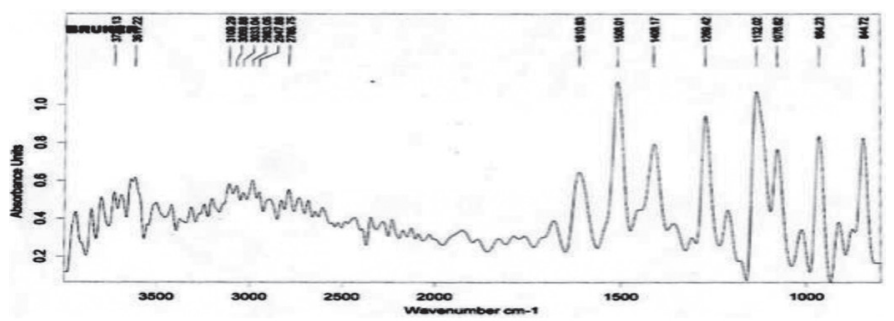

Figure 1. IR spectra of pure sulconazole nitrate IR: Infrared spectroscopy

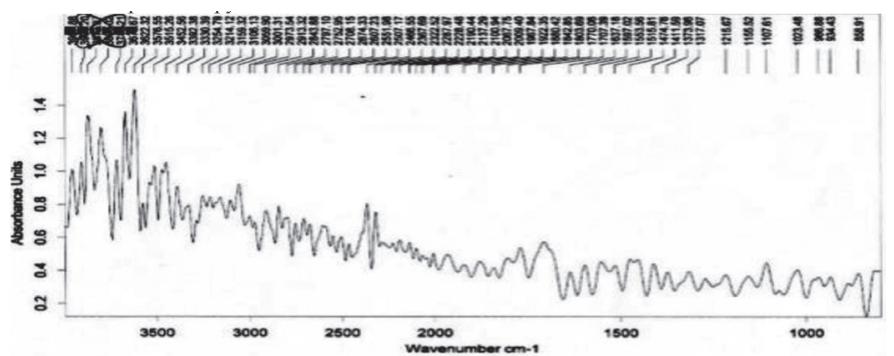

Figure 2. IR spectra of Carbopol 940P

IR: Infrared spectroscopy

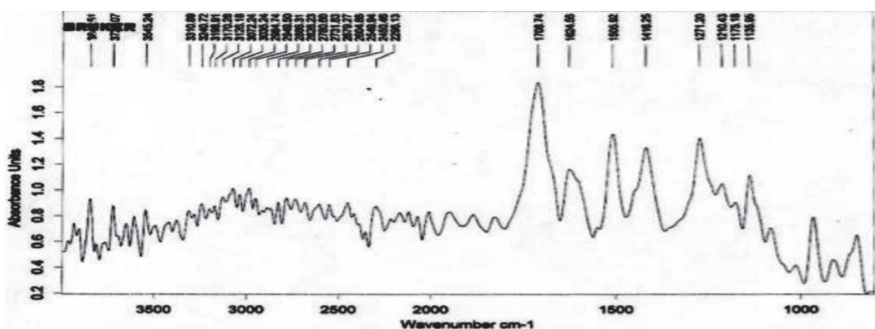

Figure 3. IR spectra of a physical mixture of sulconazole nitrate and Carbopol 934P

IR: Infrared spectroscopy

\section{Table 2. Evaluation of the centrifugation test}

\begin{tabular}{ll} 
Formulation code & Centrifugation \\
\hline F1 & Monophasic, stable \\
\hline F2 & Not stable \\
\hline F3 & Monophasic, stable \\
\hline F4 & Monophasic, stable \\
\hline F5 & Not stable \\
\hline F6 & Not stable \\
\hline
\end{tabular}

\section{Table 3. Results of freeze thawing test}

\begin{tabular}{ll} 
Formulation code & Freeze thawing \\
\hline F1 & Stable and no separation \\
\hline F3 & Stable and no separation \\
\hline F4 & Stable and no separation \\
\hline
\end{tabular}

\section{Freeze thawing test}

This test checks the stability and phase separation of formulations if found (Table 3).

\section{Determination of zeta potential}

The zeta potential value depends on the type and composition of the carrier used in the formulation. The zeta potential of F1 was -33.5 , which indicates good stability (Table 4).

\section{Determination of $\mathrm{pH}$}

$\mathrm{F} 1, \mathrm{~F} 3$, and $\mathrm{F} 4$ were in the $\mathrm{pH}$ range of 6.32-7.0, which is within the specified range for topical formulations (Table 4).

\section{Drug content}

The percentage drug content of F1, F3, and F4 was 93.05\%$95.88 \%$. This shows that the drug is uniformly distributed throughout the microemulsion. The maximum drug content was obtained for F1 (Table 4).

\begin{tabular}{llll}
\hline $\begin{array}{l}\text { Table 4. Zeta potential, } \mathrm{pH} \text {, and drug content of } \mathrm{F} 1, \mathrm{F3} \text {, and F4 } \\
\begin{array}{l}\text { Formulation } \\
\text { code }\end{array}\end{array}$ & $\begin{array}{l}\text { Zeta potential } \\
(\mathrm{mV})\end{array}$ & $\mathrm{pH}$ & $\begin{array}{l}\text { Drug content } \\
(\%)\end{array}$ \\
\hline $\mathrm{F} 1$ & $-33.5 \pm 2.3$ & $7.0 \pm 0.01$ & $95.88 \pm 0.3 \%$ \\
\hline $\mathrm{F} 3$ & $-41.2 \pm 3.4$ & $6.32 \pm 0.03$ & $91.42 \pm 0.2 \%$ \\
\hline F4 & $-38.3 \pm 2.7$ & $6.89 \pm 0.02$ & $93.05 \pm 0.4 \%$ \\
\hline
\end{tabular}

*Mean \pm SD ( $n=3), S D$ : Standard deviation

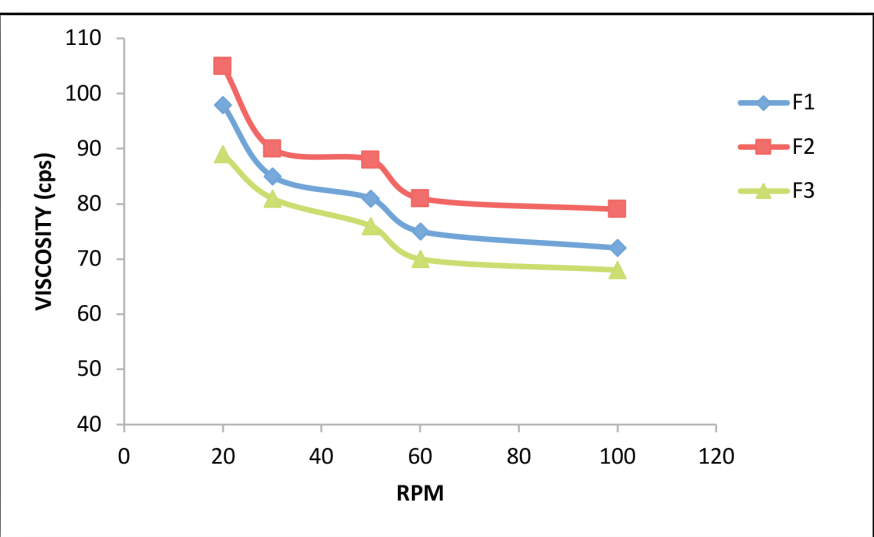

Figure 4. Rheology of sulconazole microemulsions for F1, F3, and F4

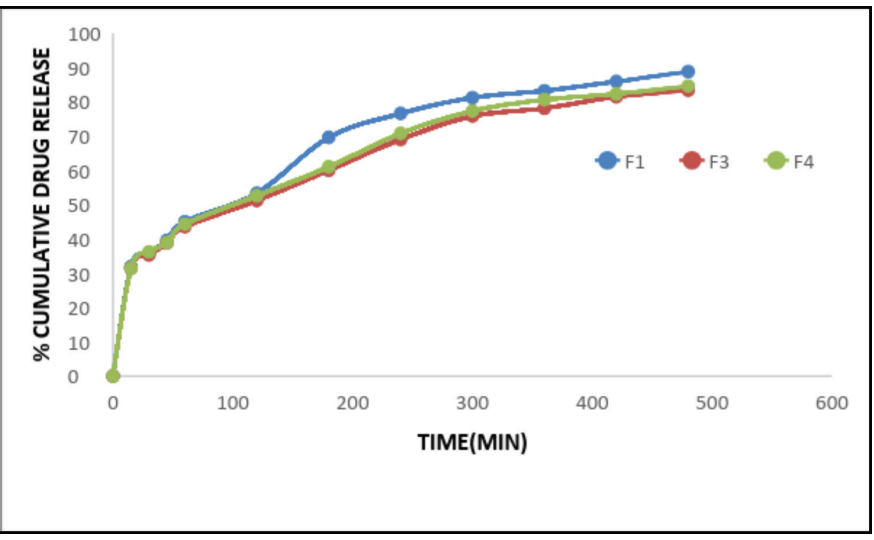

Figure 5. In vitro drug release profile of F1, F3, and F4 microemulsion gel formulations 


\section{Determination of viscosity}

The viscosity of F1, F2, and F3 microemulsion formulations at $20,30,50,60$, and $100 \mathrm{rpm}$ was measured using spindle number 92 at room temperature. The viscosity curve was plotted by taking shear rate (rpm) on the $\mathrm{x}$-axis and viscosity on the $y$-axis (Figure 4) with the data obtained (Table 5).

\section{Preparation of drug loaded microemulsion gel}

Sulconazole nitrate microemulsion (F1, F3, and F4) containing Carbopol appeared to be transparent, clear, and smooth textured. These drug-containing gel formulations were further evaluated for $\mathrm{pH}$ and drug content.

\section{Evaluation of microemulsion gel}

Drug content values were in the range of $91.5-95.5 \%$ and $\mathrm{pH}$ ranged between 7.2 and 7.8 (Table 6 ).

\section{In vitro drug release and kinetic studies}

Three microemulsion gel formulations (F1, F3, and F4) were selected for the in vitro drug release study. The \% cumulative drug release was $83.32-88.75$ at the end of $8 \mathrm{~h}$ (Figure 5). The mechanism of drug release was calculated by fitting the dissolution data to different models like Higuchi's and Korsmeyer-Peppas. The best model was selected based on the highest regression value (Figure 6).

\section{In vivo skin irritation study}

The skin irritation study was carried out on six rats, of which three were treated with placebo and three with F1. They were observed for $72 \mathrm{~h}$ to check for signs of erythema and edema on the skin surface (Figure 7 ).

\section{DISCUSSION}

From the FTIR study, the peaks that appeared for the physical mixture indicated that the drug and the gelling agents are compatible with each other.

Table 5. Viscosity of F1, F2, and F3 at different rpm

\begin{tabular}{llll}
\multirow{2}{*}{$\mathrm{rpm}$} & \multicolumn{4}{l}{ Viscosity (cps)* } \\
\cline { 2 - 4 } & $\mathrm{F} 1$ & $\mathrm{~F} 2$ & $\mathrm{F3}$ \\
\hline 20 & $98 \pm 0.01$ & $105 \pm 0.01$ & $89 \pm 0.01$ \\
\hline 30 & $85 \pm 0.07$ & $90 \pm 0.01$ & $81 \pm 0.01$ \\
\hline 50 & $81 \pm 0.02$ & $88 \pm 0.02$ & $76 \pm 0.03$ \\
\hline 60 & $75 \pm 0.03$ & $81 \pm 0.03$ & $70 \pm 0.01$ \\
\hline 100 & $72 \pm 0.02$ & $79 \pm 0.01$ & $68 \pm 0.01$ \\
\hline
\end{tabular}

*Values are mean \pm SD ( $n=3), S D$ : Standard deviation

\section{Table 6. Drug content and pH of F1 microemulsion}

\begin{tabular}{llll}
\multirow{2}{*}{ Test } & \multicolumn{3}{l}{ Drug loaded microemulsion gel } \\
\cline { 2 - 4 } & F1 & F3 & F4 \\
\hline Drug content & $95.5 \pm 0.34 \%$ & $91.5 \pm 0.26 \%$ & $92.5 \pm 0.36 \%$ \\
\hline $\mathrm{pH}$ & $7.21 \pm 0.01$ & $7.72 \pm 0.02$ & $7.81 \pm 0.02$ \\
\hline
\end{tabular}

*Values are mean \pm SD $(n=3), S D$ : Standard deviation
From the results of globe size analysis, it was observed that an increase in the ratio of the oil phase resulted in an increase in the particle size because of the decrease in the surfactant/ cosurfactant proportion. An increase in the surfactant/ cosurfactant ratio and decrease in oil ratio led to a decrease in mean particle size.

The dilution test showed that after dilution of microemulsion with water the microemulsions remained clear, indicating the good miscibility of microemulsions with water, which was used as the continuous phase.

From the centrifugation test, it was observed that F1, F3 and F4 were stable and monophasic liquids and they were further evaluated for $\mathrm{pH}$, drug content, and zeta potential.

The freeze thawing results also confirmed that all three formulations were stable and there was no phase separation.

The zeta potential of formulation F1 was found to be good and was optimized as the best formulation. The $\mathrm{pH}$ of the formulated microemulsions was within the specified skin range.

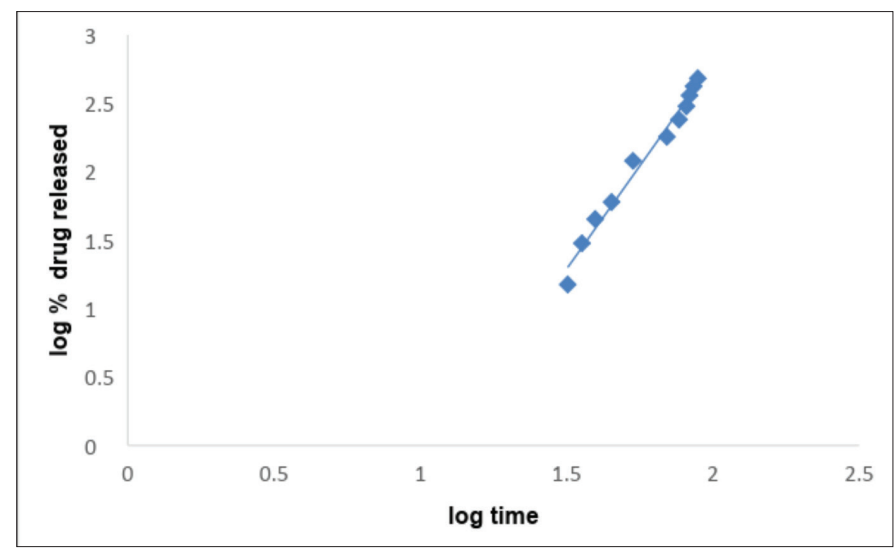

Figure 6. Korsmeyer-Peppas model for F1 microemulsion

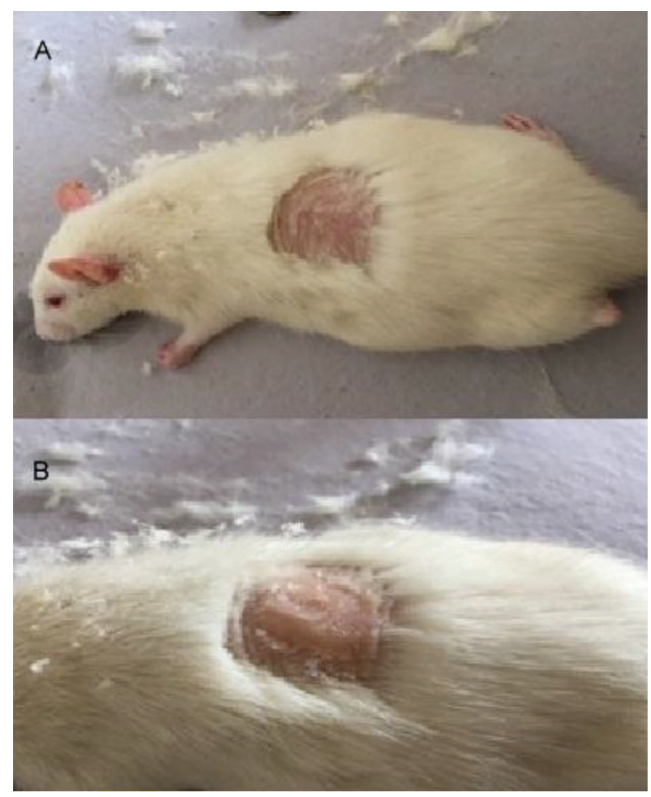

Figure 7. In vivo skin irritation test for F1 microemulsion: (A) before application, (B) after application 
From the viscosity study, all three formulations showed pseudoplastic non-newtonian flow and viscosity values decreased as the shear rates increased.

From the drug release data F1 was found to show a higher percentage of drug release in comparison to F3 and F4. This may be because spontaneous formation of microemulsion with small particle size permitted a faster rate of drug release. Thus greater permeability of the dissolved sulconazole nitrate from the microemulsion gel formulation, which can lead to higher absorption through the skin, can be expected.

F1 followed the Korsmeyer-Peppas model since the regression coefficient value was higher.

The in vivo skin irritation study showed that there was no sign of erythema or edema after $72 \mathrm{~h}$ of application of the gel and F1 was found to be safe, nontoxic, and nonirritant for application on the skin.

\section{CONCLUSION}

The microemulsion based gel of sulconazole nitrate was successfully formulated for topical delivery to treat fungal infections. The formulated gel possessed good physicochemical properties, high drug content, and sustained drug release. It was also confirmed that the formulated gel is safer for topical delivery by the in vivo studies. Based on these results, it can be concluded that a microemulsion based gel of sulconazole nitrate is promising for topical delivery against fungal infections.

\section{ACKNOWLEDGEMENTS}

The authors are thankful to Ranbaxy Laboratory, New Delhi, for providing sulconazole nitrate as a gift sample and N.G.S.M. Institute of Pharmaceutical Sciences, Nitte (Deemed to be University), Mangaluru, for providing the necessary facilities to carry out this work.

Conflicts of interest: No conflict of interest was declared by the authors. The authors alone are responsible for the content and writing of this article.

\section{REFERENCES}

1. Kikwai L, Babu RJ, Prado R, Kolot A, Armstrong CA, Ansel JC, Singh M. In vitro and In vivo evaluation of topical formulation of spantide II. AAPS Pharm Sci Tech. 2005;6:565-572.
2. Kumar R, Katare OP, Lecithin organogels as a potential phospholipid structured for topical drug delivery, a review. AAPS Pharm Sci Tech. 2005;6:298-310.

3. Chein YW. Transdermal therapeutic systems. In: Robinson JR, Lee VHL, eds.Text book of Controlled drug delivery: fundamentals and application, $2^{\text {nd }}$ ed. New York: Marcel Dekker Inc; 1987:524-549.

4. Chen H, Chang X, Du D, Li J, Xu H, Yang X. Microemulsion based hydrogel formulation of ibuprofen for topical delivery. Int $\mathrm{J}$ Pharm. 2006;315:52-58.

5. Benjamin EJ, Lee M, Tom J, Lin LY, Hanesian M, Wu D. Stabilization of sulconazole nitrate in topical powder formulation. Int $\mathrm{J}$ Pharma. 1983;14:209-211.

6. Badawi AA, Nour SA, Sakran WS, El-Mancy SMS. Preparation and evaluation of microemulsion systems containing salicylic acid. AAPS Pharm Sci Tech. 2009;10:1081-1084.

7. Brime B, Moreno MA, Frutos G, Ballesteros MP, Frutos P. Amphotericin $B$ in oil in water Lecithin-based microemulsions: Formulation and toxicity evaluation. J Pharm Sci. 2002;91:1178-1185.

8. Karasulu YH, Karabulut B, Göker E, Güneri T, Gabor F. Controlled release of Methotrexate from w/o microemulsion and its in vitro antitumor activity. Drug Deliv. 2007;14:225-233.

9. Bajpai M, Sharma PK, Mittal A. A study of oleic acid base for the tropical delivery of dexamethasone microemulsion formulations. Asian J Pharm. 2009;208-214.

10. Dhamankar AK, Manwar JV, Kumbhar DD. The novel formulation design of o/w microemulsion of ketoprofen for improving transdermal absorption. Int J Pharm. 2009;1:1449-1457.

11. Bansal K, Rawat MK, Jain A, Rajput A, Chaturvedi TP. Development of satranidazole mucoadhesive gel for the treatment of periodontitis. AAPS Pharm Sci Tech. 2009;10(3):716-723.

12. Basha NB, Prakasam K, Goli D. Formulation and evaluation of gel containing fluconazole-antifungal agent. Int J Drug Dev Res. 2011;3:109128.

13. Kumar A, Kushwaha VS, Sharma P. Pharmaceutical microemulsion: Formulation, characterization and drug deliveries across skin. Int $\mathrm{J}$ Drug Dev Res. 2014;6:1-21. 